\title{
Valorization of Wasted Black Tea as a Low-Cost Adsorbent for Nickel and Zinc Removal from Aqueous Solution
}

\author{
Amirhossein Malakahmad, Sandee Tan, and Saba Yavari \\ Department of Civil and Environmental Engineering, Universiti Teknologi PETRONAS, 32610 Bandar Seri Iskandar, Malaysia \\ Correspondence should be addressed to Amirhossein Malakahmad; amirhossein@petronas.com.my
}

Received 6 November 2015; Revised 4 March 2016; Accepted 3 April 2016

Academic Editor: Anuska Mosquera-Corral

Copyright (C) 2016 Amirhossein Malakahmad et al. This is an open access article distributed under the Creative Commons Attribution License, which permits unrestricted use, distribution, and reproduction in any medium, provided the original work is properly cited.

\begin{abstract}
Characteristics and efficiency of wasted black tea (WBT) were investigated as a low-cost sorbent in removal of $\mathrm{Ni}^{2+}$ and $\mathrm{Zn}^{2+}$ ions from aqueous solution. Initial findings showed WBT potential to be applied as an effective sorbent due to high concentrations of carbon and calcium and high porosity and availability of functional groups. Sorption dynamics were studied with varying $\mathrm{pH}$, contact time, and adsorbent dose. Maximum percentages of metal ions removal were recorded at $\mathrm{pH}$ 5, contact time 250 min, and $20 \mathrm{~g} / \mathrm{L}$ of adsorbent concentration. Binary metal sorption studies showed that $\mathrm{Ni}^{2+}$ and $\mathrm{Zn}^{2+}$ do not compete with each other for available sorption sites, so the adsorption trend in binary system appears similar to monocomponent metal adsorption. Evaluation of the isotherms confirmed that WBT has high value of adsorption capacity. Sorption data fitted well with both Freundlich and Langmuir models. In the optimum conditions, maximum capacity of WBT could reach up to $90.91 \mathrm{mg}-\mathrm{Ni} / \mathrm{g}$ adsorbent and $166.67 \mathrm{mg}-\mathrm{Zn} / \mathrm{g}$ adsorbent. This experiment demonstrated the ability of tea waste as an effective, sustainable, and low-cost adsorbent for removal of the heavy metal ions.
\end{abstract}

\section{Introduction}

Nickel $\left(\mathrm{Ni}^{2+}\right)$ is an essential element which is desired for the human health in small amount. However, at high concentrations or prolonged exposures, it can cause health problems such as allergy, blood and heart disorders, chronic bronchitis, and even cancer [1]. Zinc $\left(\mathrm{Zn}^{2+}\right)$ is also an essential micronutrient, but too much of zinc intake causes acute and chronic toxicity. Based on the Environmental Protection Agency (EPA) guidelines the maximum concentrations of $\mathrm{Ni}^{2+}$ and $\mathrm{Zn}^{2+}$ allowed in drinking water are 0.1 and $5 \mathrm{ppm}$, respectively [2]. $\mathrm{Ni}^{2+}$ and $\mathrm{Zn}^{2+}$ are among the most common heavy metals in the wastewater of the industries such as electroplating, electronics, batteries, and metal treatment and fabrication. Electroplating industry is one of the major sources of nickel and zinc pollutions. It is reported that the initial $\mathrm{Ni}^{2+}$ and $\mathrm{Zn}^{2+}$ concentrations in a typical electroplating industry range from 20 to $120 \mathrm{mg} / \mathrm{L} \mathrm{[3].}$

Unlike the majority of organic pollutants, trace elements cannot be subjected to degradation into harmless products through biological processes. So, they can be a potential threat for living organisms due to their bioaccumulation characteristics [4]. Hence, it is required to remove the harmful heavy metals from the contaminated discharges using other methods. Many techniques such as chemical precipitation, electrochemical treatment, ion exchange, filtration, reverse osmosis, and solvent extraction have been employed for treatment of wastewater containing heavy metals [5]. However, most of these conventional techniques are often non-eco-friendly and very costly especially when the heavy metals concentration is in the range of $10-100 \mathrm{mg} / \mathrm{L}[6,7]$. The adsorption of contaminants is adopted as an efficient and promising technique comparable to the current methods in decrease of heavy metals concentrations to acceptable levels. Adsorption is considered as an economically effective treatment method, if low-cost adsorbents are utilized. Data in Table 1 compare the efficiencies of the sorption technique with some common methods used in removal of $\mathrm{Ni}^{2+}$ and $\mathrm{Zn}^{2+}$ from wastewater.

The commonly used adsorbents are material containing organic carbon (such as activated carbon, biochar, and plant residues) and many inorganic chemicals and clay [8]. 
TABLE 1: Efficiencies of the current methods and sorption technique in removal of $\mathrm{Ni}^{2+}$ and $\mathrm{Zn}^{2+}$.

\begin{tabular}{|c|c|c|c|}
\hline \multirow{2}{*}{ Technique } & \multicolumn{2}{|c|}{ Removal efficiency $(\%)^{*}$} & \multirow{2}{*}{ Reference } \\
\hline & $\mathrm{Ni}^{2+}$ & $\mathrm{Zn}^{2+}$ & \\
\hline Chemical precipitation & 98.4 & 99 & {$[13,14]$} \\
\hline Electrochemical & 98 & 96 & {$[15,16]$} \\
\hline Ion exchange & 93.6 & 100 & {$[17,18]$} \\
\hline Filtration & 99.1 & 98 & {$[19,20]$} \\
\hline Reverse osmosis & 99.3 & 98.9 & {$[21]$} \\
\hline Adsorption & 82 & 99.8 & {$[17,22]$} \\
\hline
\end{tabular}

${ }^{*}$ Initial metals concentrations of less than $200 \mathrm{mg} / \mathrm{L}$.

The necessity of finding inexpensive, renewable, and more effective adsorbents encourages the investigation of different materials. In recent years, a wide range of studies has been conducted to remove heavy metal ions from aqueous environments using sorption methods with different materials. The utilization of agricultural wastes as sorbent can promote the decrease of environmental problems related to green wastes management and their disposal. A vast variety of green wastes have been evaluated for sorption studies such as rice husk [9], wheat bran [10], corn cobs [11], tree leaves and barks [12], and aquatic weeds [7].

Thousands of tons of wasted black tea are produced and disposed unutilized in tea shops, restaurants, and houses every day. Wasted black tea is resistant to biodegradation and becomes a matter for disposal as waste. The main constituents of tea leaves are cellulose, hemicelluloses, lignin, tannins, and proteins. The functional groups in these compounds are mainly hydroxyl, oxyl, aromatic carboxylate, amino, sulfonic, and phenolic groups which promote the physicochemical interactions for substances sorption including heavy metals [23]. There are some studies on use of factory tea waste as adsorbent [24-26]. But there are limited reports on the use of wasted black tea after brewing as a low-cost adsorbent and its effects on decreasing the concentrations of metallic substances. Therefore, in this study, after characterization of wasted black tea, its adsorptive performance and efficiency as sorbent for removal of $\mathrm{Ni}^{2+}, \mathrm{Zn}^{2+}$, and mixture of $\mathrm{Ni}^{2+}$ and $\mathrm{Zn}^{2+}$ in a binary system from synthetic wastewater were investigated. The $\mathrm{Ni}^{2+}$ and $\mathrm{Zn}^{2+}$ concentrations were set to be in range of their actual concentrations in electroplating industry.

\section{Materials and Methods}

2.1. Preparation of the Adsorbent. Wasted black tea was collected from a local Chinese restaurant located in Kuantan, Malaysia. The samples were black tea (Camellia sinensis L.) leaves that have been discarded after the process of making the tea drink in boiling water. The additional coloring, dirt, milk, and sugar were removed by washing the samples with boiled water several times. They were then rinsed with distilled water, oven-dried at $105^{\circ} \mathrm{C}$ for 24 hours, and passed through a $3.35 \mathrm{~mm}$ sieve before the experiment.
2.2. Characteristics Determination. The particle size distribution of the samples was determined using sieve analysis (opening size from 14 to $2 \mathrm{~mm}$ ). The initial $\mathrm{pH}$ was measured by soaking of samples in distilled water $(\mathrm{pH} 7)$ for 24 hours and reading the water $\mathrm{pH}$ using a $\mathrm{pH}$ meter probe (sensION4). The samples were covered with gold sputters using a sputter coater (SC7640) and measured for the surface morphology and elements content. The surface morphology was characterized using Field-Emission Scanning Electron Microscope (FE-SEM, Supra 55 VP, Carl Zeiss, Germany) and elemental analysis was conducted by energy-dispersive $\mathrm{X}$ ray spectroscopy (EDXs, Supra 55 VP, Carl Zeiss, Germany). The functional groups on the surface of adsorbent were determined by Fourier Transform Infrared Spectroscopy (FTIR, Spectrum one, PerkinElmer, US).

\subsection{Preparation of Aqueous Solution Containing Heavy Metals.} The stock solutions of $\mathrm{Ni}^{2+}$ and $\mathrm{Zn}^{2+}$ were prepared separately at concentration of $1000 \mathrm{mg} / \mathrm{L}$ by dissolving $4.05 \mathrm{~g}$ of nickel chloride salt $\left(\mathrm{NiCl}_{2} \cdot 6 \mathrm{H}_{2} \mathrm{O}\right)$ and $4.40 \mathrm{~g}$ of zinc sulfate heptahydrate salt $\left(\mathrm{ZnSO}_{4} \cdot 7 \mathrm{H}_{2} \mathrm{O}\right)$ in $1000 \mathrm{~mL}$ distilled water. Working solutions were obtained in the range of 1 to $100 \mathrm{ppm}$ by diluting of the standard solutions with distilled water resembling the range of $\mathrm{Ni}^{2+}$ and $\mathrm{Zn}^{2+}$ concentrations found in effluent released from typical electroplating industry [3]. Medusa-Hydra equilibrium software was used for prediction of different compounds produced in the aqueous solution containing $\mathrm{Ni}^{2+}$ and $\mathrm{Zn}^{2+}$. The hydrolysis constants ( $\log K$ ) for each compound were extracted from the software and $\mathrm{pH}$ of each component was calculated accordingly.

2.4. Adsorption Behavior. The influences of $\mathrm{pH}$, contact time, and adsorbent dose on adsorption efficiency were studied to determine the optimum values of these factors in sorption mechanism. To conduct these experiments, $250 \mathrm{~mL}$ Erlenmeyer flasks containing solutions with known concentrations of $\mathrm{Ni}^{2+}$ and $\mathrm{Zn}^{2+}$ were kept in a closed environment at ambient temperature $\left(28^{\circ} \mathrm{C}\right)$. The $\mathrm{pH}$ of the solutions for both $\mathrm{Ni}^{2+}$ and $\mathrm{Zn}^{2+}$ was varied within the range of 2 to 6. The solutions' $\mathrm{pH}$ was adjusted using $0.1 \mathrm{~N} \mathrm{HCl}$ and $0.1 \mathrm{~N} \mathrm{NaOH}$. This range is justified based on the previous researches which declared that the optimum $\mathrm{pH}$ for removal of $\mathrm{Ni}^{2+}$ and $\mathrm{Zn}^{2+}$ from aqueous solution is in the range of 4 to $5[23,24]$. The $\mathrm{pH}$ was measured by a $\mathrm{pH}$ meter probe. The concentration of adsorbent was standardized at $20 \mathrm{~g} / \mathrm{L}$ and the mixtures were shaken for $60 \mathrm{~min}$. The adsorbent dosage used in the experiment was adjusted to allow for $30-80 \%$ of the added adsorbate to be sorbed at equilibrium [27]. To study the effects of contact time on sorption dynamics, the time was set in a range between 0 and $250 \mathrm{~min}$. The concentrations of the heavy metals were measured at $50 \mathrm{~min}$ intervals. The agitation speed was set at 150 rotations per min (rpm). An orbital shaker was used to provide adequate contact between adsorbent and adsorbate. The impact of adsorbent dose on sorption was investigated in the range of $2-20 \mathrm{~g} / \mathrm{L}$. To measure the concentration of metals ions, the contents of the flasks were filtered through filter paper (Whatman, $0.45 \mu \mathrm{m}$ ) and then analyzed using atomic adsorption spectrophotometer (AAS, AA-6800, Shimadzu, 
Japan). The removal percentage of the ions was calculated using

$$
\text { Adsorption uptake }(\%)=\frac{\left(C_{o}-C_{t}\right)}{C_{o}} \times 100,
$$

where $C_{o}$ is the initial concentration of the ions and $C_{t}$ is the concentration at time $t$.

2.5. Binary Metal Adsorption. $50 \mathrm{~mL}$ of each metal solution containing $100 \mathrm{ppm}$ of $\mathrm{Ni}^{2+}$ and $\mathrm{Zn}^{2+}$ was used for this study. $20 \mathrm{~g} / \mathrm{L}$ of the sample was added and the $\mathrm{pH}$ was adjusted in the range of 2 to 6 . Samples were shaken and the dose of heavy metals was determined after $60 \mathrm{~min}$.

2.6. Sorption Isotherms. To determine the sorption isotherms of adsorbate on the surface of adsorbent, the batch equilibration procedure was applied. $20 \mathrm{~g} / \mathrm{L}$ of the adsorbent was added separately to the aqueous solutions containing a range of $\mathrm{Ni}^{2+}$ and $\mathrm{Zn}^{2+}$ concentrations between 1 and $70 \mathrm{mg} / \mathrm{L}$ and then agitated at $150 \mathrm{rpm}$ for $60 \mathrm{~min}$. The $\mathrm{pH}$ of all solutions was standardized at $\mathrm{pH}$ 5. The experiment was conducted at room temperature $\left(28^{\circ} \mathrm{C}\right)$. After equilibration, the concentration of each metal ion in the solutions was measured using AAS in triplicate. Any decrease in mass of the ions in the solutions was assumed to be due to adsorption onto the adsorbent and in this way the sorbed concentrations were calculated. A relationship was then established between the amount of ions adsorbed per unit weight of adsorbent and the ions concentration in the solution at equilibrium. The most frequently used equation for substances sorption is Freundlich and Langmuir adsorption equation which can be described by (2).

Freundlich model is as follows:

$$
\frac{x}{m}=K_{f} C_{e}^{1 / n},
$$

where $x$ is the mass of the sorbed adsorbate $(\mathrm{mg}), m$ is the unit mass of adsorbent $(\mathrm{g}), K_{f}$ is the Freundlich capacity factor, $C_{e}$ is the adsorbate concentration in the solution at equilibrium $(\mathrm{mg} / \mathrm{L})$, and $1 / n$ is the Freundlich intensity parameter.

Langmuir model is as follows:

$$
\frac{x}{m}=\frac{Q_{o} b C_{e}}{1+b C_{e}},
$$

where $Q_{o}$ is the maximum adsorption of the substrate to the adsorbent and $b$ is Langmuir constant. The empirical constants in the Freundlich and Langmuir isotherms were determined by plotting graphs using (4) and (5).

Freundlich isotherm is

$$
\log \left(\frac{x}{m}\right) \text { versus } \log C_{e} \text {. }
$$

Langmuir isotherm is

$$
\frac{C_{e}}{(x / m)} \text { versus } C_{e} \text {. }
$$

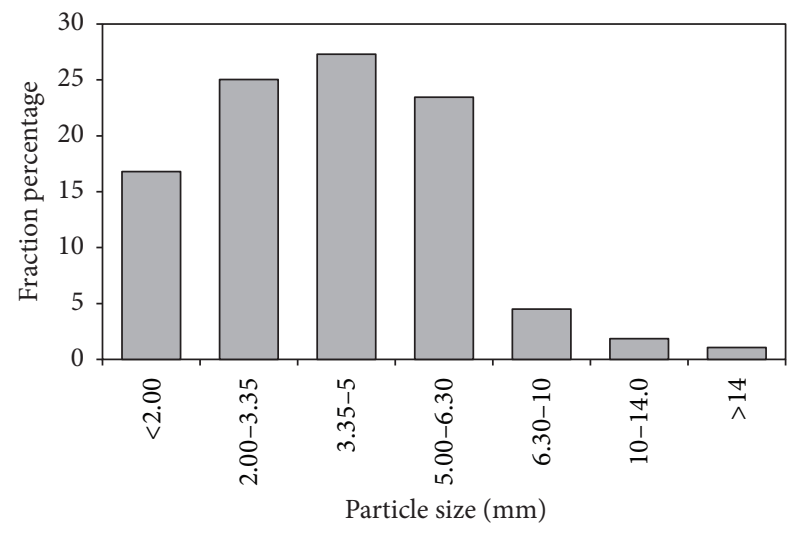

FIgure 1: Particle size distribution of the wasted black tea.

To compare the capability of Freundlich equation with Langmuir model in prediction of adsorption, average absolute deviation (AAD\%) was calculated using

$$
\mathrm{AAD} \%=100 \times \frac{\sum \sqrt{\left(Y_{\text {Actual }}-Y_{\text {Model }}\right)^{2} / Y_{\text {Actual }}^{2}} .}{\text { Number of tests }} .
$$

\section{Results and Discussion}

3.1. Adsorbent Characteristics. Particle size distribution of the wasted black tea sample is expressed in Figure 1. Particle size distribution determines the surface area of a sorbent. Smaller particle size accounts for larger surface area available for adsorption. Based on the outcomes, the size of particles was mostly $3.35 \mathrm{~mm}$ and thus the adsorbent with the sizes $3.35 \mathrm{~mm}$ and below was used in this study.

Based on the results, the initial $\mathrm{pH}$ was 4.76 which is almost the optimum $\mathrm{pH}$ for removal of $\mathrm{Ni}^{2+}$ and $\mathrm{Zn}^{2+}$ [24] and therefore minute preparations were needed to use the wasted black tea for adsorption. Suitability of adsorbent $\mathrm{pH}$ is a considerable advantage and it reduces the application cost further as adjustment of $\mathrm{pH}$ requires addition of chemicals and usage of extra energy and labor. Figure 2 indicates the concentration of determined elements in the sample using EDX spectroscopy. Based on the results, wasted black tea is rich in elements such as carbon and calcium similar to the activated carbon. The high concentrations of these elements allow the adsorbent to exhibit high sorption capacity [28].

The surface morphology of adsorbent obtained by SEM and the results of FTIR spectra are presented in Figure 3. Based on the photograph, there are a large volume of voids on the surface which result in great surface area, abundant adsorption sites, and therefore a high sorption capacity. This allows the adsorbate to efficiently adhere to the surface of the adsorbent. The FTIR peaks represent various chemical bonds in the sample which can be effective in sorption activity. The broad peak at $3421 \mathrm{~cm}^{-1}$ is assigned to $-\mathrm{OH}$ polar groups. The bands at $2920-2851$ and $1451-1319 \mathrm{~cm}^{-1}$ are assigned to aliphatic $-\mathrm{CH}_{2}$ units. The sorption peaks at $1637-1542 \mathrm{~cm}^{-1}$ are assigned to aromatic $\mathrm{C}=\mathrm{O}$ and $\mathrm{C}=\mathrm{C}$ vibration indicating presence of hard-carbon components. This confirms the EDX 


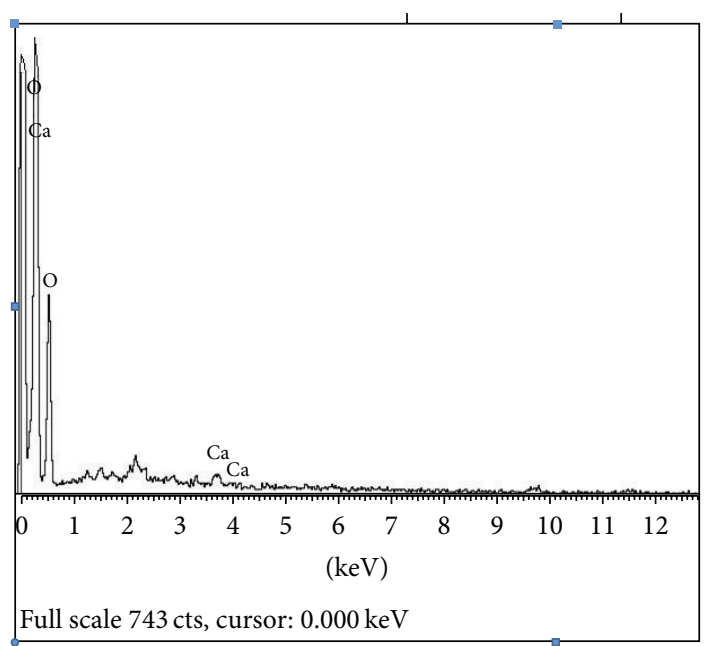

FIGURE 2: EDS curve of tea waste.

results specifying the high carbon content measured in the sample. An adsorption peak at $1240 \mathrm{~cm}^{-1}$ is attributed to aromatic $\mathrm{CO}-$ and phenolic $-\mathrm{OH}$ bond. The peaks around $1157-1034 \mathrm{~cm}^{-1}$ correspond to aliphatic $\mathrm{C}-\mathrm{O}-\mathrm{C}$ and alcohol $-\mathrm{OH}$ representing oxygenated functional groups of cellulosic and ligneous components. The oxygen-containing functional groups have been reported that play important roles in the capacity of organic sorbents in adsorption of heavy metals [29]. Therefore, it can be concluded that the physical sorption of $\mathrm{Ni}^{2+}$ and $\mathrm{Zn}^{2+}$ by tea waste was related to the coulombic forces which are electrostatic energy of interaction between the metal ions and the adsorbent's oxygenated functional groups [22].

3.2. Effect of Solution $p H$ on Adsorption. Figure 4 shows the removal percentage of $\mathrm{Ni}^{2+}$ and $\mathrm{Zn}^{2+}$ in $\mathrm{pH}$ ranging from 2 to 6 . The amount of metal ions sorption enhanced as the $\mathrm{pH}$ increased. The sorption of $\mathrm{Ni}^{2+}$ showed a gentle increasing trend and reached its maximum (about 60\%) at $\mathrm{pH}$ 6. This result was similar to that of Soares et al. [30] who evaluated the effects of soil $\mathrm{pH}$ (ranged from 3 to 5) on $\mathrm{Ni}^{2+}$ adsorption in Brazilian soils. Based on their results, the metal sorption increased (20-90\%) when the $\mathrm{pH}$ was raised from 4 to 6 . As it is presented in Figure 4, the highest percentage (about $80 \%$ ) of $\mathrm{Zn}^{2+}$ sorption occurred at $\mathrm{pH} 5$ and stayed unchanged while the $\mathrm{pH}$ reached 6 . Several studies have reported that the $\mathrm{pH}$ ranging from 4 to 5 is the optimum values for removal of $\mathrm{Zn}^{2+}$ from aqueous solution. According to Malkoc and Nuhoglu [24], the maximum sorption of $\mathrm{Ni}^{2+}$ was recorded at $\mathrm{pH}$ 4.0. Wasewar et al. [25] investigated a wide range of $\mathrm{pH}$ from 2 to 12 and reported that the best $\mathrm{Zn}^{2+}$ removal happened at $\mathrm{pH} 4.2$. It has been shown that, at lower $\mathrm{pH}$ value, the $\mathrm{H}^{+}$ions compete with metal cations for the electrostatic surface charges in the system decreasing the percentage of sorption. It is well known that the sorption of $\mathrm{Ni}^{2+}$ and $\mathrm{Zn}^{2+}$ is affected by the species of the ions in aqueous solutions which are strongly controlled by $\mathrm{pH}$ values. The reduction in adsorption at higher $\mathrm{pH}$ can be attributed
TABLE 2: Hydrolysis constants $(\log K)$ and $\mathrm{pH}$ of $\mathrm{Ni}^{2+}$ and $\mathrm{Zn}^{2+}$ species.

\begin{tabular}{lccccc}
\hline $\mathrm{Zn}^{2+}$ species & $\log K$ & $\mathrm{pH}$ & $\mathrm{Ni}^{2+}$ species & $\log K$ & $\mathrm{pH}$ \\
\hline $\mathrm{Zn}(\mathrm{OH})_{2}$ & -16.4 & 8.3 & $\mathrm{Ni}(\mathrm{OH})_{2}$ & -20.01 & 7.1 \\
$\mathrm{Zn}(\mathrm{OH})_{4}{ }^{-2}$ & -41.3 & 5.5 & $\mathrm{Ni}(\mathrm{OH})_{4}{ }^{-2}$ & -45.0 & 4.5 \\
$\mathrm{Zn}_{2}(\mathrm{OH})_{6}{ }^{-2}$ & -54.3 & 6.5 & $\mathrm{Ni}_{2} \mathrm{OH}$ & -9.8 & 10.5 \\
$\mathrm{Zn}_{2} \mathrm{OH}^{+3}$ & -9.0 & 10.8 & $\mathrm{Ni}_{4}(\mathrm{OH})_{4}{ }^{+4}$ & -27.9 & 9.9 \\
$\mathrm{Zn}_{4}(\mathrm{OH})_{4}{ }^{+4}$ & -27.0 & 10.3 & $\mathrm{NiOH}^{+}$ & -9.5 & 5.3 \\
$\mathrm{ZnOH}^{+}$ & -7.5 & 10.2 & & & \\
\hline
\end{tabular}

to the precipitation of metal hydroxides of these ions [24]. Table 2 shows the overall hydrolysis constants $(\log K)$ of the $\mathrm{Ni}^{2+}$ and $\mathrm{Zn}^{2+}$ hydroxyl species that can be used to calculate the relative distribution of the ions species in different $\mathrm{pH}$ values. Overall, the $\mathrm{pH}$ of both $\mathrm{Ni}^{2+}$ and $\mathrm{Zn}^{2+}$ compounds in solution remained below the $\mathrm{pH}$ that sedimentation of nickel and zinc compounds exhibited.

3.3. Effect of Contact Time on Adsorption. The variation in $\mathrm{Ni}^{2+}$ and $\mathrm{Zn}^{2+}$ sorption with varying contact time is illustrated in Figure 5. Based on the results, the amount of sorption showed an increasing tendency as the contact time increased, but it was more significant for zinc. Removal percentage of $\mathrm{Zn}^{2+}$ was just below $60 \%$ in contact time of $50 \mathrm{~min}$ and then reached up to $86.7 \%$ in time of $250 \mathrm{~min}$, while for $\mathrm{Ni}^{2+}$ the changes in sorption percentage were just $5 \%$ during the range of agitation times. These results are similar to those obtained by Malkoc and Nuhoglu [24] that showed that the increase in agitation rate improves efficiency of metal ions removal. Longer period of contact between the adsorbent and adsorbate increases the amount of sorption; however the adsorption rate reduces as the contact time increases [25]. This is due to the decrease of adsorption sites on the adsorbent while it is being saturated by the heavy metals. Based on the results, the optimum contact time for sorption was around 50-60 min.

3.4. Effect of Adsorbent Dose on Adsorption. Figure 6 illustrates the percentage of $\mathrm{Ni}^{2+}$ and $\mathrm{Zn}^{2+}$ sorption with increasing the adsorbent dose. Removal of the metal ions showed similar increasing pattern as the adsorbent concentrations rose from 2 to $20 \mathrm{~g} / \mathrm{L}$. Sorption percentage of nickel and zinc increased by $41 \%$ and $47 \%$, respectively. The increase of adsorbent concentration means the increase of surface area and more available sorption sites which increases the amount of metal ions removal [24].

3.5. Binary Metal Adsorption. The sorption percentage of $\mathrm{Ni}^{2+}$ and $\mathrm{Zn}^{2+}$ in the binary system within the $\mathrm{pH}$ range of 2 to 6 is presented in Figure 7. The results of the simultaneous adsorption showed that the sorption capacity for both heavy metals in binary metal sorption was still very similar to single metal ions sorption. So, the binary adsorption exhibits the noninteraction behavior where the mixture of metal ions has no effect on the adsorption of the ions in the mixture. This can be attributed to similar charge intensity and ionic radius 


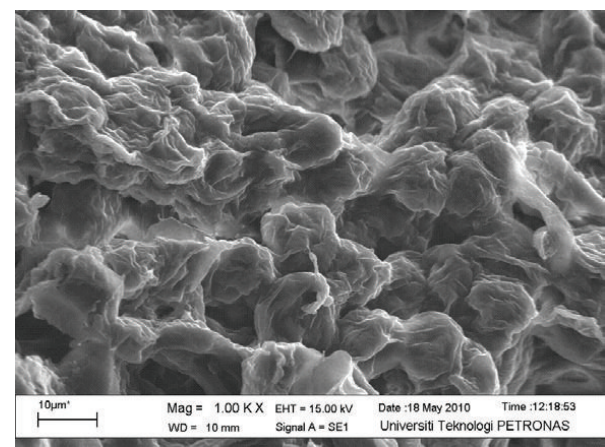

(a)

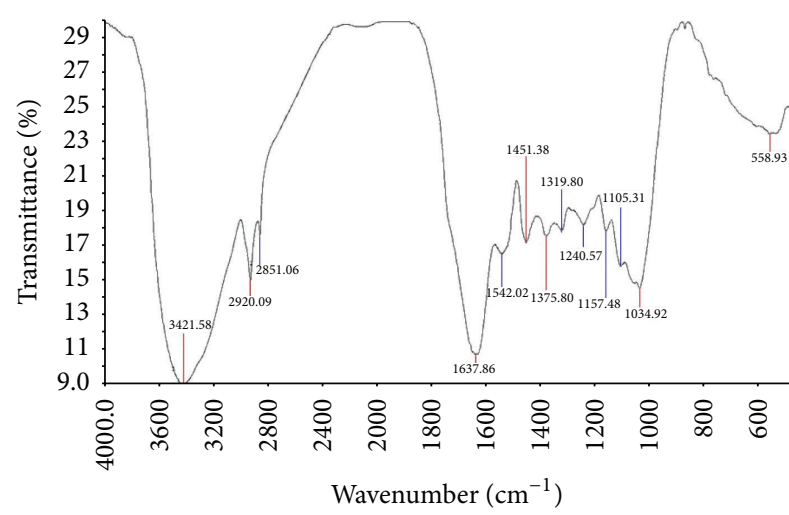

(b)

FIGURE 3: SEM photograph of wasted black tea at 1000x magnification (a) and FTIR spectra of the wasted black tea (b).

TABLE 3: The parameters of Freundlich and Langmuir adsorption equations.

\begin{tabular}{lcccccccc}
\hline \multirow{2}{*}{ Adsorbate } & \multicolumn{3}{c}{ Freundlich constants } & \multicolumn{3}{c}{ Langmuir constants } \\
& $K_{f}(\mathrm{mg} / \mathrm{g})$ & $1 / n$ & $R^{2}$ & AAD\% & $Q_{o}(\mathrm{mg} / \mathrm{g})$ & $b$ & $R^{2}$ & $\mathrm{AAD}^{2}$ \\
\hline $\mathrm{Ni}^{2+}$ & 20.80 & 0.24 & 0.976 & 3.49 & 90.91 & 0.224 & 0.949 \\
$\mathrm{Zn}^{2+}$ & 16.22 & 0.36 & 0.994 & 2.92 & 166.67 & 0.133 & 0.917 & 3.37 \\
\hline
\end{tabular}

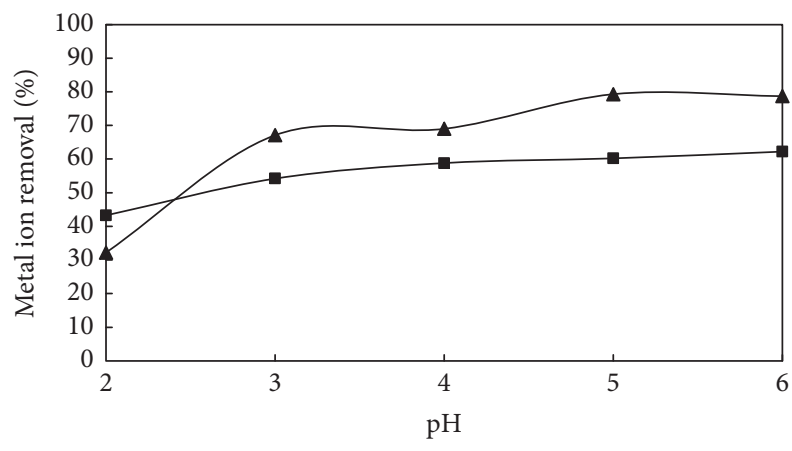

FIGURE 4: Percentage of $\mathrm{Ni}^{2+}(\boldsymbol{\square})$ and $\mathrm{Zn}^{2+}(\boldsymbol{\Delta})$ ions removal with varying $\mathrm{pH}$.

of the metal ions. The ionic radii values of $\mathrm{Ni}^{2+}$ and $\mathrm{Zn}^{2+}$ are 0.69 and $0.68 \AA$, respectively [43].

3.6. Adsorption Isotherms. The outcomes of evaluation of sorption isotherms of $\mathrm{Ni}^{2+}$ and $\mathrm{Zn}^{2+}$ on the wasted black tea are presented in Figure 8. Both Freundlich and Langmuir adsorption equations were investigated. The data fitted well with both models. However, correlation coefficients $\left(R^{2}\right)$ showed higher values in Freundlich equation compared to Langmuir model. The AAD\% for Freundlich and Langmuir equations indicated that both models were almost similar and precise in prediction of $\mathrm{Ni}^{2+}$ and $\mathrm{Zn}^{2+}$ sorption. The related parameters are listed in Table 3. Magnitude of the sorption coefficients $\left(Q_{o}\right.$ and $K_{f}, y$-intercepts) in both equations signifies the high sorption affinity of wasted black tea for nickel and zinc.

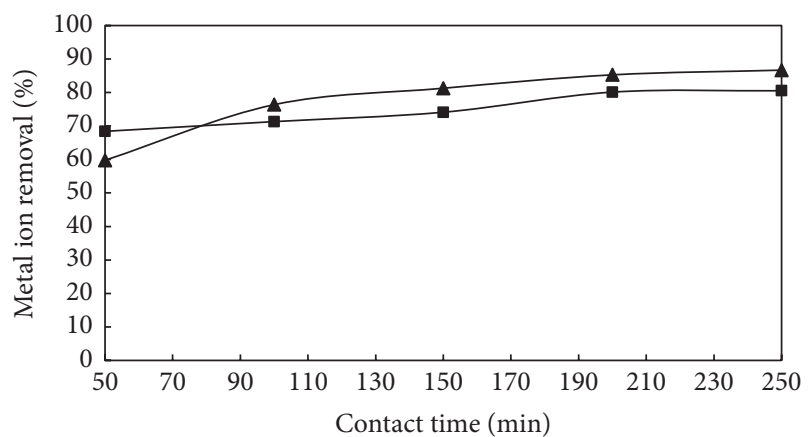

Figure 5: Percentage of $\mathrm{Ni}^{2+}(\boldsymbol{\square})$ and $\mathrm{Zn}^{2+}(\boldsymbol{\Delta})$ ions removal with varying contact time.

Table 4 presents comparison of the adsorption capacity of wasted black tea used in this study with other studies aimed at removal of $\mathrm{Ni}^{2+}$ or $\mathrm{Zn}^{2+}$. The sorption capacity $\left(Q_{o}\right.$ value) of wasted black tea showed a magnitude of $90.91 \mathrm{mg}-\mathrm{Ni} / \mathrm{g}$ adsorbent, while that for powdered activated carbon was reported to be $31.08 \mathrm{mg} / \mathrm{g}$ [34]. Although the adsorbent dose in the present study was 1.7 times more, the sorption performance of tea waste was still higher than the potential of activated carbon. $Q_{o}$ value for wasted black tea was $166.67 \mathrm{mg}-\mathrm{Zn} / \mathrm{g}$ adsorbent. In spite of higher applied adsorbent dose (2\%), the sorption capacity of wasted black tea was comparable with the capacity of bagasse-based activated carbon in sorption of $\mathrm{Zn}^{2+}$ ion $(54 \mathrm{mg} / \mathrm{g}$ ) [37]. The high sorption potential of wasted black tea was achieved without any activation or additional treatment of the biomass. Therefore, wasted black tea can be still considered as a cost-effective and sustainable 
TABLE 4: The capacity of different adsorbents for $\mathrm{Ni}^{2+}$ and $\mathrm{Zn}^{2+}$ removal.

\begin{tabular}{|c|c|c|c|}
\hline Adsorbent & Adsorbent mass to solution volume ratio & Sorption capacity (mg/g) & Reference \\
\hline \multicolumn{4}{|c|}{$\mathrm{Ni}^{2+}$ removal } \\
\hline Sphagnum moss peat & $0.4: 100$ & 9.18 & [31] \\
\hline Baker's yeast & $0.1: 100$ & 11.40 & {$[32]$} \\
\hline Chlorella sorokiniana (FBCS) & $0.1: 100$ & 48.08 & {$[33]$} \\
\hline Powdered activated carbon & $1.2: 100$ & 31.08 & {$[34]$} \\
\hline Waste tea & $1.5: 100$ & 18.42 & {$[24]$} \\
\hline Waste tea (formaldehyde-treated) & $0.2: 100$ & 120.50 & {$[35]$} \\
\hline Black wasted tea & $2: 100$ & 90.91 & This study \\
\hline \multicolumn{4}{|c|}{$\mathrm{Zn}^{2+}$ removal } \\
\hline Olive oil mill residues & $0.4: 100$ & 52.91 & {$[36]$} \\
\hline Bagasse-based activated carbon & $0.6: 100$ & 54.00 & [37] \\
\hline Date pits-based activated carbon & $0.02: 100$ & 120.5 & {$[38]$} \\
\hline Chitosan & $0.25: 100$ & 58.83 & [39] \\
\hline Waste tea leaves & $0.15: 100$ & 11.76 & {$[40]$} \\
\hline Black tea waste & $1: 100$ & 12.24 & [41] \\
\hline Tea factory waste & $0.4: 100$ & 8.9 & {$[25]$} \\
\hline Tea leaves (hydrazine monohydrate-exhausted) & $0.125: 100$ & 79.76 & {$[42]$} \\
\hline Wasted black tea & $2: 100$ & 166.67 & This study \\
\hline
\end{tabular}

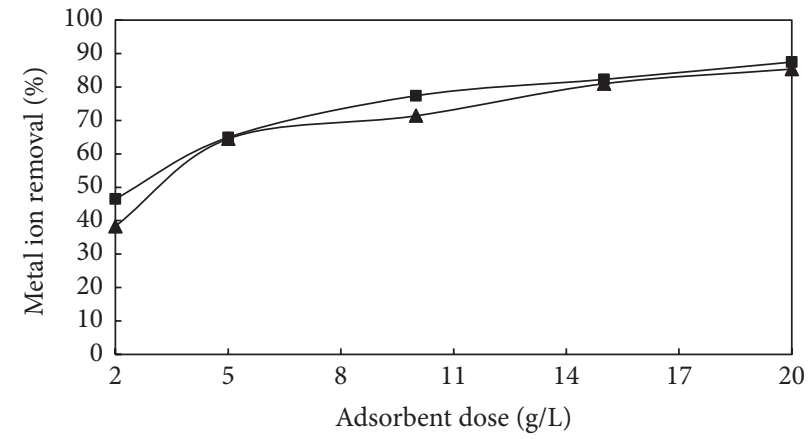

Figure 6: Percentage of $\mathrm{Ni}^{2+}(\boldsymbol{\square})$ and $\mathrm{Zn}^{2+}(\boldsymbol{\Delta})$ ions removal with varying adsorbent dose.

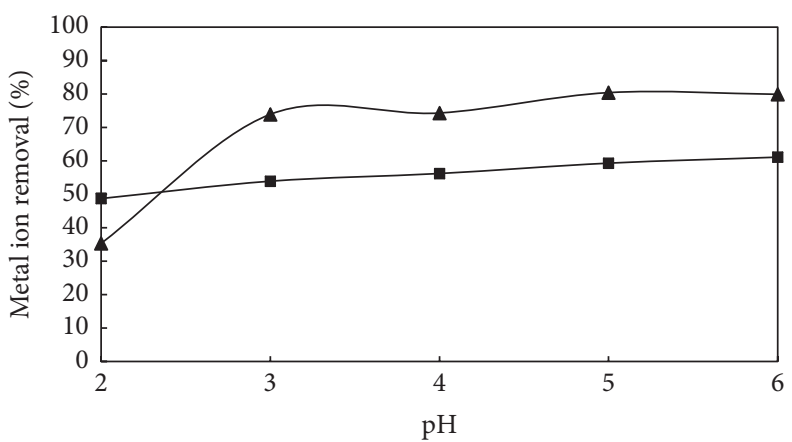

FIGURE 7: Percentage of $\mathrm{Ni}^{2+}(\boldsymbol{\square})$ and $\mathrm{Zn}^{2+}(\boldsymbol{\Delta})$ ions removal with varying $\mathrm{pH}$ in binary metal sorption.

adsorbent compared to other adsorbents for remediation of aquatic systems.

The same results were obtained by Ahluwalia and Goyal [44] who showed the high sorption capacity of tea leaves for heavy metals with $Q_{o}$ values of $515.03 \mathrm{mg} / \mathrm{g}$ and $785.5 \mathrm{mg} / \mathrm{g}$ for $\mathrm{Ni}^{2+}$ and $\mathrm{Zn}^{2+}$, respectively (adsorbent dose of $0.5 \%$ ).

\section{Conclusion}

The findings in this study indicate that wasted black tea is effective adsorbent for the removal of nickel and zinc from wastewater due to its unique properties including the high content of carbon, high porosity, and reactive functional 

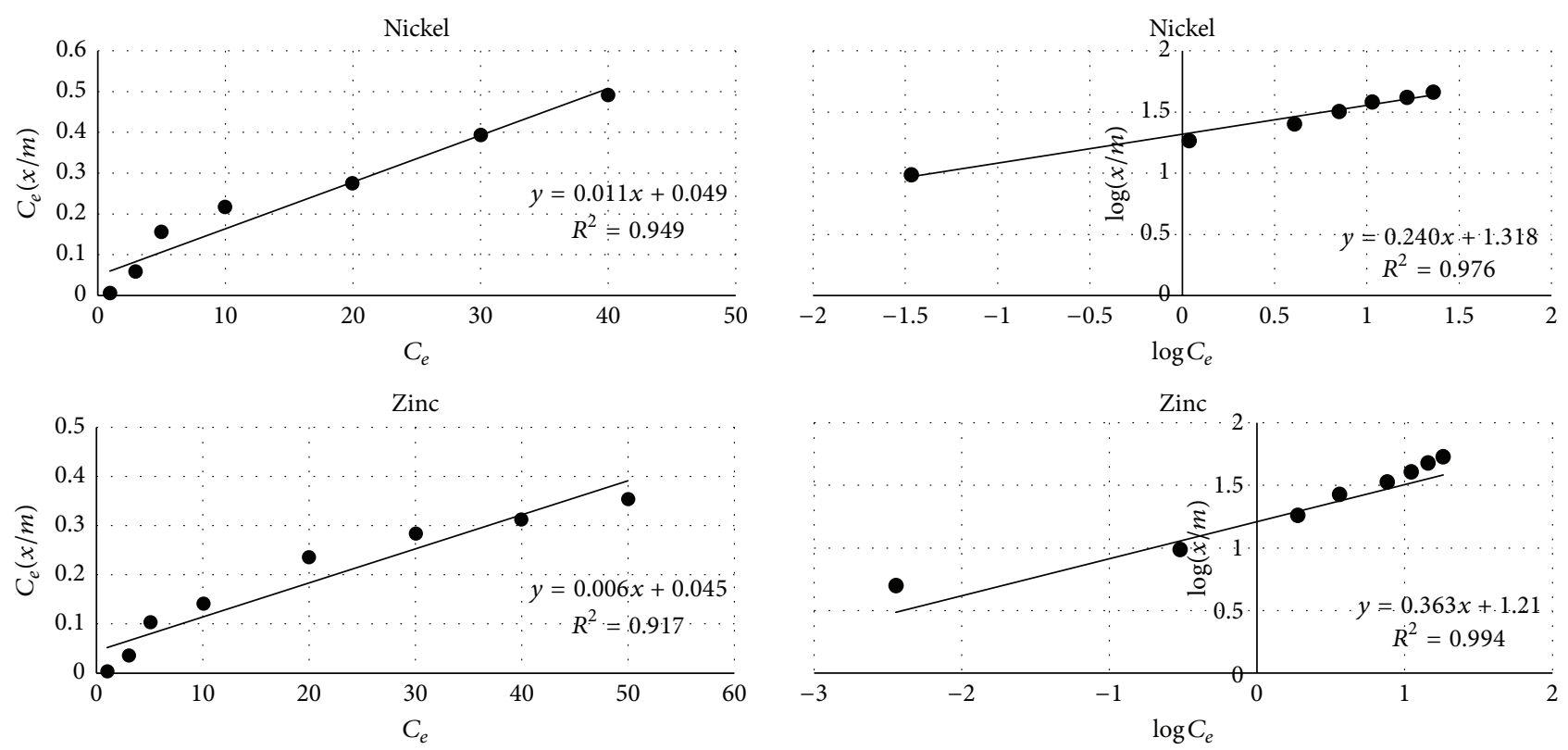

FIGURE 8: Langmuir and Freundlich isotherms for the adsorption of $\mathrm{Ni}^{2+}$ and $\mathrm{Zn}^{2+}$.

sites. Wasted black tea as a salvaged material has a very low economic value and since it was found that its original $\mathrm{pH}$ is proper for sorption of nickel and zinc, its utilization in industries having nickel and zinc in their discharges seems to be possible. Wasted black tea had shown good performance in removal of nickel and zinc from aqueous solution in both monocomponent metal and binary systems. Maximum adsorptions of 90.91 and $166.67 \mathrm{mg} / \mathrm{g}$ of nickel and zinc, respectively, indicate that wasted black tea is a competitive adsorbent for industrial applications. However, a feasibility study is recommended to take place when the wasted black tea is in plan to be used for industrial discharge treatment. Some factors including collection, transportation, and preparation costs of wasted black tea should be considered in the feasibility study before its applications at large scales.

\section{Competing Interests}

The authors declare that they have no competing interests.

\section{References}

[1] R. B. Hayes, "The carcinogenicity of metals in humans," Cancer Causes and Control, vol. 8, no. 3, pp. 371-385, 1997.

[2] EPA, Drinking Water Regulations under the Safe Drinking Water Act, Factsheet, 1990, http://nepis.epa.gov/Exe/ZyPDF .cgi/910187Z0.PDF?Dockey=910187Z0.PDF.

[3] S. Hasan, M. A. Hashim, and B. S. Gupta, "Adsorption of $\mathrm{Ni}\left(\mathrm{SO}_{4}\right)$ on Malaysian rubber-wood ash," Bioresource Technology, vol. 72, no. 2, pp. 153-158, 2000.

[4] M. Carrier, A. Loppinet-Serani, C. Absalon, F. Marias, C. Aymonier, and M. Mench, "Conversion of fern (Pteris vittata L.) biomass from a phytoremediation trial in sub-and supercritical water conditions," Biomass and Bioenergy, vol. 35, no. 2, pp. 872883, 2011.
[5] J. Wang and C. Chen, "Biosorbents for heavy metals removal and their future," Biotechnology Advances, vol. 27, no. 2, pp. 195226, 2009.

[6] Z. R. Holan and B. Volesky, "Biosorption of lead and nickel by biomass of marine algae," Biotechnology and Bioengineering, vol. 43, no. 11, pp. 1001-1009, 1994.

[7] S. Dixit, S. Dhote, R. Dubey, H. M. Vaidya, and R. J. Das, "Sorption characteristics of heavy metal ions by aquatic weed," Desalination and Water Treatment, vol. 20, no. 1-3, pp. 307-312, 2010.

[8] R. Qadeer and S. Akhtar, "Kinetics study of lead ion adsorption on active carbon," Turkish Journal of Chemistry, vol. 29, no. 1, pp. 95-99, 2005.

[9] M. M. D. Zulkali, A. L. Ahmad, and N. H. Norulakmal, “Oryza sativa L. husk as heavy metal adsorbent: optimization with lead as model solution," Bioresource Technology, vol. 97, no. 1, pp. 2125, 2006.

[10] M. A. Farajzadeh and A. B. Monji, "Adsorption characteristics of wheat bran towards heavy metal cations," Separation and Purification Technology, vol. 38, no. 3, pp. 197-207, 2004.

[11] T. Vaughan, C. W. Seo, and W. E. Marshall, "Removal of selected metal ions from aqueous solution using modified corncobs," Bioresource Technology, vol. 78, no. 2, pp. 133-139, 2001.

[12] S. Al-Asheh, F. Banat, R. Al-Omari, and Z. Duvnjak, "Predictions of binary sorption isotherms for the sorption of heavy metals by pine bark using single isotherm data," Chemosphere, vol. 41, no. 5, pp. 659-665, 2000.

[13] M. Fuerhacker, T. M. Haile, D. Kogelnig, A. Stojanovic, and B. Keppler, "Application of ionic liquids for the removal of heavy metals from wastewater and activated sludge," Water Science and Technology, vol. 65, no. 10, pp. 1765-1773, 2012.

[14] F. Fu, L. Xie, B. Tang, Q. Wang, and S. Jiang, "Application of a novel strategy-advanced fenton-chemical precipitation to the treatment of strong stability chelated heavy metal containing wastewater," Chemical Engineering Journal, vol. 189-190, pp. 283-287, 2012. 
[15] A. Khelifa, S. Moulay, and A. W. Naceur, "Treatment of metal finishing effluents by the electroflotation technique," Desalination, vol. 181, no. 1-3, pp. 27-33, 2005.

[16] R. G. Casqueira, M. L. Torem, and H. M. Kohler, "The removal of zinc from liquid streams by electroflotation," Minerals Engineering, vol. 19, no. 13, pp. 1388-1392, 2006.

[17] M. E. Argun, "Use of clinoptilolite for the removal of nickel ions from water: kinetics and thermodynamics," Journal of Hazardous Materials, vol. 150, no. 3, pp. 587-595, 2008.

[18] K. Athanasiadis and B. Helmreich, "Influence of chemical conditioning on the ion exchange capacity and on kinetic of zinc uptake by clinoptilolite," Water Research, vol. 39, no. 8, pp. 15271532, 2005.

[19] M. A. Barakat and E. Schmidt, "Polymer-enhanced ultrafiltration process for heavy metals removal from industrial wastewater," Desalination, vol. 256, no. 1-3, pp. 90-93, 2010.

[20] J.-H. Huang, G.-M. Zeng, C.-F. Zhou, X. Li, L.-J. Shi, and S.B. He, "Adsorption of surfactant micelles and $\mathrm{Cd}^{2+} / \mathrm{Zn}^{2+}$ in micellar-enhanced ultrafiltration," Journal of Hazardous Materials, vol. 183, no. 1-3, pp. 287-293, 2010.

[21] U. Ipek, "Removal of $\mathrm{Ni}(\mathrm{II})$ and $\mathrm{Zn}$ (II) from an aqueous solutionby reverse osmosis," Desalination, vol. 174, no. 2, pp. 161-169, 2005.

[22] A. Agrawal, K. K. Sahu, and B. D. Pandey, "Removal of zinc from aqueous solutions using sea nodule residue," Colloids and Surfaces A: Physicochemical and Engineering Aspects, vol. 237, no. 1-3, pp. 133-140, 2004.

[23] O. A. Al-Mashaqbeh and R. G. McLaughlan, "Effect of compost aging on zinc adsorption characteristics," Journal of Environmental Chemical Engineering, vol. 2, no. 1, pp. 392-397, 2014.

[24] E. Malkoc and Y. Nuhoglu, "Investigations of nickel(II) removal from aqueous solutions using tea factory waste," Journal of Hazardous Materials, vol. 127, no. 1-3, pp. 120-128, 2005.

[25] K. L. Wasewar, M. Atif, B. Prasad, and I. M. Mishra, "Batch adsorption of zinc on tea factory waste," Desalination, vol. 244, no. 1-3, pp. 66-71, 2009.

[26] L. S. Thakur and M. Parmar, "Adsorption of heavy metal $\left(\mathrm{Cu}^{2+}, \mathrm{Ni}^{2+}\right.$ and $\left.\mathrm{Zn}^{2+}\right)$ from synthetic waste water by tea waste adsorbent," International Journal of Chemical and Physical Sciences, vol. 2, pp. 6-19, 2013.

[27] X.-Y. Yu, C.-L. Mu, C. Gu, C. Liu, and X.-J. Liu, "Impact of woodchip biochar amendment on the sorption and dissipation of pesticide acetamiprid in agricultural soils," Chemosphere, vol. 85, no. 8, pp. 1284-1289, 2011.

[28] G. K. L. Matta, M. A. S. D. Barros, R. Lambrecht, E. A. da Silva, and O. C. da Motta Lima, "Dynamic isotherms of dye in activated carbon," Materials Research, vol. 11, no. 3, pp. 365-369, 2008.

[29] B. Chen, D. Zhou, and L. Zhu, "Transitional adsorption and partition of nonpolar and polar aromatic contaminants by biochars of pine needles with different pyrolytic temperatures," Environmental Science and Technology, vol. 42, no. 14, pp. 51375143, 2008.

[30] M. R. Soares, J. C. Casagrande, and E. R. Mouta, "Nickel adsorption by variable charge soils: effect of $\mathrm{pH}$ and ionic strength," Brazilian Archives of Biology and Technology, vol. 54, no. 1, pp. 207-220, 2011.

[31] Y. S. Ho, D. A. John Wase, and C. F. Forster, "Batch nickel removal from aqueous solution by sphagnum moss peat," Water Research, vol. 29, no. 5, pp. 1327-1332, 1995.
[32] V. Padmavathy, P. Vasudevan, and S. C. Dhingra, "Biosorption of nickel(II) ions on Baker's yeast," Process Biochemistry, vol. 38, no. 10, pp. 1389-1395, 2003.

[33] N. Akhtar, J. Iqbal, and M. Iqbal, "Removal and recovery of nickel(II) from aqueous solution by loofa sponge-immobilized biomass of Chlorella sorokiniana: characterization studies," Journal of Hazardous Materials, vol. 108, no. 1-2, pp. 85-94, 2004.

[34] M. Rao, A. V. Parwate, and A. G. Bhole, "Removal of $\mathrm{Cr}^{6+}$ and $\mathrm{Ni}^{2+}$ from aqueous solution using bagasse and fly ash," Waste Management, vol. 22, no. 7, pp. 821-830, 2002.

[35] J. Shah, M. R. Jan, A. Ul Haq, and M. Zeeshan, "Equilibrium, kinetic and thermodynamic studies for sorption of $\mathrm{Ni}$ (II) from aqueous solution using formaldehyde treated waste tea leaves," Journal of Saudi Chemical Society, vol. 19, no. 3, pp. 301-310, 2015.

[36] A. Hawari, Z. Rawajfih, and N. Nsour, "Equilibrium and thermodynamic analysis of zinc ions adsorption by olive oil mill solid residues," Journal of Hazardous Materials, vol. 168, no. 2-3, pp. 1284-1289, 2009.

[37] D. Mohan and K. P. Singh, "Single- and multi-component adsorption of cadmium and zinc using activated carbon derived from bagasse-an agricultural waste," Water Research, vol. 36, no. 9, pp. 2304-2318, 2002.

[38] N. S. Awwad, A. A. El-Zahhar, A. M. Fouda, and H. A. Ibrahium, "Removal of heavy metal ions from ground and surface water samples using carbons derived from date pits," Journal of Environmental Chemical Engineering, vol. 1, no. 3, pp. 416423, 2013.

[39] Z. Reddad, C. Gerente, Y. Andres, and P. Le Cloirec, "Adsorption of several metal ions onto a low-cost biosorbent: kinetic and equilibrium studies," Environmental Science and Technology, vol. 36, no. 9, pp. 2067-2073, 2002.

[40] T. W. Tee and A. R. M. Khan, "Removal of lead, cadmium and zinc by waste tea leaves," Environmental Technology Letters, vol. 9, no. 11, pp. 1223-1232, 1988.

[41] R. R. Mohammed, "Removal of heavy metals from waste water using black tea waste," Arabian Journal for Science and Engineering, vol. 37, pp. 1505-1520, 2012.

[42] B. Shrestha, P. L. Homagai, M. R. Pokhrel, and K. N. Ghimire, "Exhausted Tea Leaves-a low cost bioadsorbent for the removal of Lead (II) and Zinc (II) ions from their aqueous solution," Journal of Nepal Chemical Society, vol. 30, pp. 123-129, 2013.

[43] S. Çay, A. Uyanik, and A. Özaşik, "Single and binary component adsorption of copper(II) and cadmium(II) from aqueous solutions using tea-industry waste," Separation and Purification Technology, vol. 38, no. 3, pp. 273-280, 2004.

[44] S. S. Ahluwalia and D. Goyal, "Removal of heavy metals by waste tea leaves from aqueous solution," Engineering in Life Sciences, vol. 5, no. 2, pp. 158-162, 2005. 

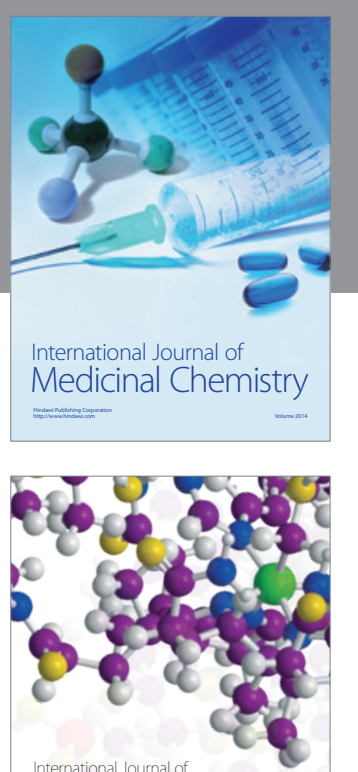

Carbohydrate Chemistry

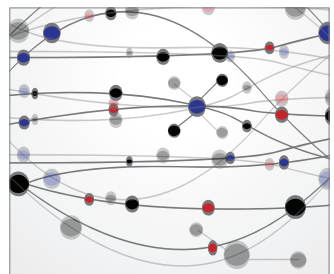

The Scientific World Journal
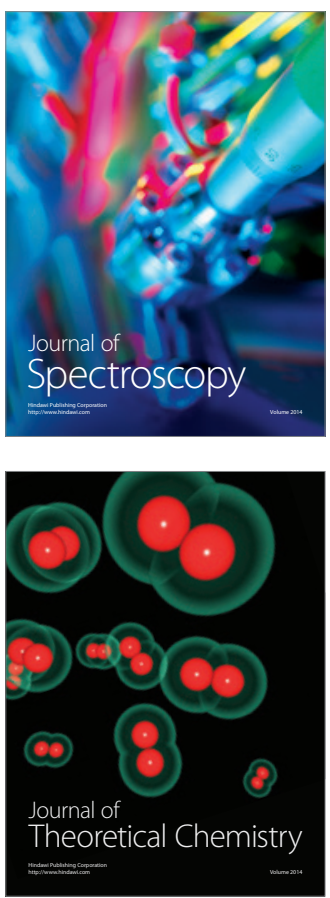
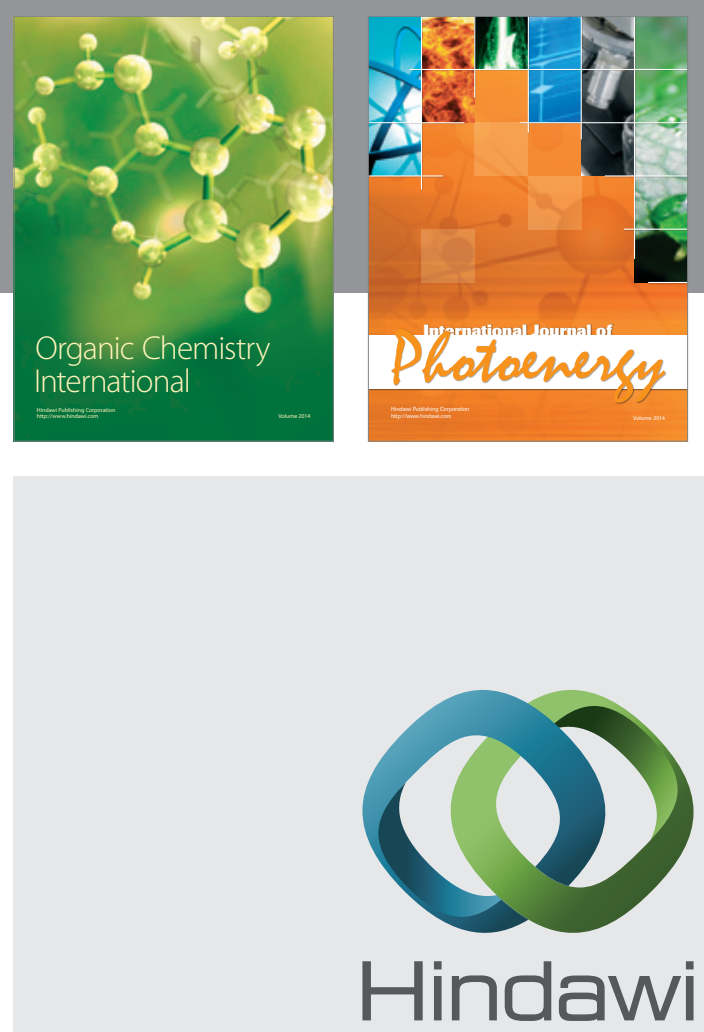

Submit your manuscripts at

http://www.hindawi.com

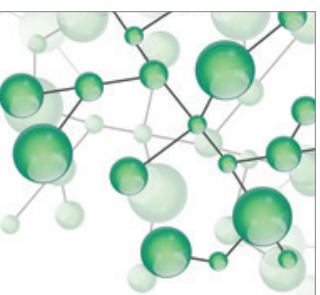

International Journal of

Inorganic Chemistry

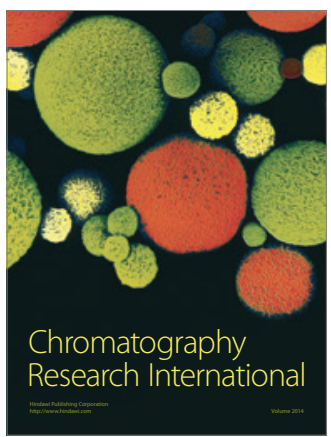

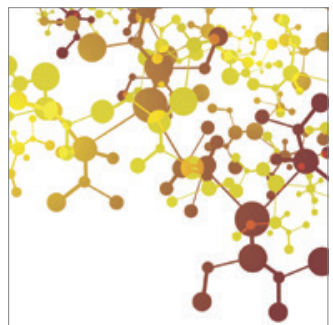

Applied Chemistry
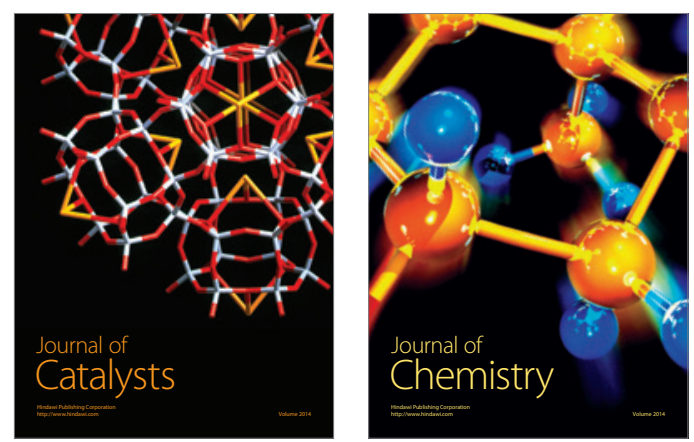
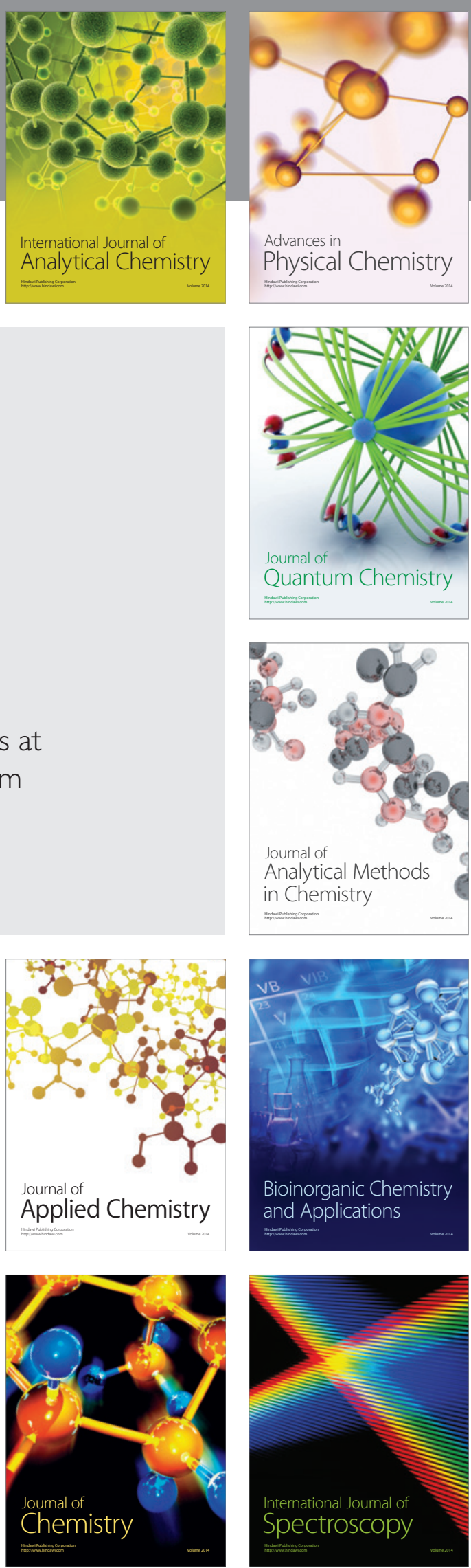